\title{
Euthanasia in Belgium - 16 years after its legalization
}

\author{
Eutanazja w Belgii - 16 lat po legalizacji \\ Iwona Piękoś-Lorenc' ${ }^{(1 D}$, Małgorzata Piecuch ${ }^{1}$ (D), Weronika Gajdzik' ${ }^{(D)}$, Agata Wypych-Ślusarska² \\ ${ }^{1}$ Studenckie Koło Naukowe przy Zakładzie Epidemiologii, Wydział Nauk o Zdrowiu w Bytomiu, \\ Śląski Uniwersytet Medyczny w Katowicach \\ 2Zakład Epidemiologii, Wydział Nauk o Zdrowiu w Bytomiu, Śląski Uniwersytet Medyczny w Katowicach
}

\section{ABSTRACT}

INTRODUCTION: Euthanasia is generally defined as an act or negligence that causes death, and consequently, interruption of the suffering of an incurably ill person.

MATERIAL AND METHODS: The analysis was based on the data of the European Institute of Bioethics. The main source of information was the Reports of the Belgian Federal Committee for Euthanasia Control and Evaluation Nos. $1-8$.

RESULTS: Just a year after legalizing this practice in Belgium, 235 people were subjected to 'assisted death'. In 2017 , the number of euthanasia procedures exceeded 2300. In the years 2002-2017 a total of 17,063 euthanasia procedures were performed. In recent years, the age structure of people undergoing euthanasia has changed. The number of people from the age of 80 and up is increasing, and it decreases at the age of 40-59. The main places of the death of patients remain the home and hospital.

\section{CONCLUSIONS:}

1. Since the legalization of euthanasia in Belgium, the number of people submitting to this procedure has been steadily increasing.

2. In recent years, euthanasia in the patient's home and in nursing homes is more often observed.

3. The most common reasons for euthanasia include neoplastic diseases.

\section{KEY WORDS}

euthanasia, Belgium, assisted suicide, incurable diseases

\section{STRESZCZENIE}

WSTĘP: Eutanazja to pojęcie ogólnie definiowane jako czyn bądź zaniedbanie powodujące śmierć, a w konsekwencji przerwanie dotychczasowego cierpienia osoby nieuleczalnie chorej.

MATERIAŁ I METODY: Analizę przeprowadzono na podstawie danych Europejskiego Instytutu Bioetyki. Główne źródło informacji stanowiły Raporty Belgijskiego Federalnego Komitetu ds. Kontroli i Oceny Eutanazji nr 1-8.

WYNIKI: Już rok po zalegalizowaniu eutanazji w Belgii 235 osób zostało poddanych „wspomaganej śmierci”. W roku 2017 liczba eutanazji przekroczyła 2300. W latach 2002-2017 wykonano łącznie 17063 eutanazje. Na przełomie ostatnich lat zmieniała się struktura wieku osób poddających się eutanazji. Zwiększa się liczba osób od 80 roku życia wzwyż, a zmniejsza w wieku 40-59 lat. Głównym miejscem śmierci pacjentów pozostaje dom i szpital.

Received: $21.03 .2019 \quad$ Revised: 06.05.2019 Accepted: $20.04 .2020 \quad$ Published online: 28.02 .2021
Address for correspondence: Iwona Piękoś-Lorenc, Studenckie Koło Naukowe przy Zakładzie Epidemiologii, Wydział Nauk o Zdrowiu w Bytomiu, Śląski
Uniwersytet Medyczny w Katowicach, ul. Piekarska 18, 41-902 Bytom, Polska, tel. +48 533 406 851, e-mail: iwona.piekoslorenc@gmail.com

Copyright @ Śląski Uniwersytet Medyczny w Katowicach www.annales.sum.edu.pl 


\section{WNIOSKI:}

1. Od momentu legalizacji eutanazji w Belgii liczba osób poddających się temu działaniu stale wzrasta.

2. W ostatnich latach częściej obserwuje się przeprowadzanie eutanazji w domu pacjenta oraz w domach opieki.

3. Spośród najczęstszych przyczyn eutanazji wymienia się choroby nowotworowe.

\section{SŁOWA KLUCZOWE}

eutanazja, Belgia, samobójstwo wspomagane, nieuleczalne choroby

\section{INTRODUCTION}

Euthanasia is generally defined as an act or failure to act that causes death, with consequent cessation of the suffering of a terminally patient. It is an act that leads to the direct termination of life by a person in the terminal stage or by medical personnel at the request of that person [1]. At present, euthanasia is ever more frequently treated as the free choice of every person to decide to end their life. Although it is still very controversial, in many countries we can observe the development of legislation related to regulating the administration of this procedure $[1,2,3]$.

The laws of many countries include a division of euthanasia into active and passive. The former involves the doctor to consciously and actively cause or accelerate the patient's death, while the latter involves the cessation of therapeutic actions in the patient, which leads to their death [4].

In countries where euthanasia is legal, the person committing it can do so with the help of an assistant, but only if he or she has no selfish motives. The assistant cannot make personal gains as a result of the act of euthanasia [2].

Belgium legalised euthanasia as the second country in the world, on 28 May 2002, about three years following a public debate involving government committees. It was based on the experiences of the Netherlands and Oregon, and the public was confident that any flaws in Dutch law would be addressed and resolved in Belgian legislation $[2,5]$. According to Belgian law, euthanasia is defined as the deliberate taking of a person's life at their request. At the same time, the doctor meeting this request is not subject to criminal prosecution provided that certain conditions are met. Above all, the patient's condition has to be grave and accompanied by considerable physical or mental suffering. At the same time, the patient must be legally competent and aware at the time of making the decision.

The decision should be voluntary, carefully considered and not made under coercion. Before the euthanasia procedure is performed, the doctor is obliged to inform the patient about their condition, life expectancy and discuss palliative treatment options as well as available therapies. At the same time, the doctor must be certain of the constant physical and mental suffering caused by the illness and consult another independent and competent doctor on the terminal character of the patient's condition. If the consulting doctor determines that the patient will not die shortly, then the patient's condition should be consulted with another doctor. For instance, a psychiatrist or a specialist in the patient's illness.

The patient's request for euthanasia is in the form of a document made in writing by the patient or a person designated by the patient in the case the patient is not able to do so. It must be an adult and one having no material benefit related to the patient's death. This document is attached to the patient's medical history. The patient may cancel this document at any time.

An amended law extending the right to euthanasia to minors, regardless of their age, entered into force in Belgium on 13 February 2014 [5]. The adoption of this law has resulted in Belgium being the first country in the world to allow legal euthanasia among children [1]. This study aims to present epidemiological data on the number and reasons for euthanasia in Belgium between 2002 and 2017.

\section{MATERIAL AND METHODS}

The analysis was based on data from the Institut Européen de Bioéthique-European Institute of Bioethics (IEB-EIB). The main source of information was the Reports of the Belgian Federal Commission for Euthanasia Control and Evaluation (Commission fédérale de Contrôle et d'Évaluation de l'Euthanasie, Rapports aux Chambres législatives) Nos. 1-8 [7,8,9,10,11,12,13,14]. The data on the number of euthanasia procedures performed in 2002-2017, including the reasons for euthanasia, age and sex of euthanised patients, as well as the place of its performance, are presented.

\section{RESULTS}

The number of euthanasia procedures in Belgium has been increasing steadily since its legalisation (Figure 1). One year following introduction of the law, 235 people decided on 'assisted death'.

Three years later, in 2006, this number nearly doubled, which was an $82.5 \%$ increase compared to 2003 . A significant increase in the number of persons undergoing euthanasia continued until 2014 and then stabilised between 2015 and 2016. In 2017, the number of acts of euthanasia carried out increased by $13.9 \%$ compared to the previous year. Between 2002 and 2017, euthanasia was performed a total of 17,063 times in Belgium.

Following an analysis of the percentage of acts of euthanasia performed based on sex, it can be observed 
that men, more often than women, decide to end their lives in this way (Figure 2).

These differences were particularly evident soon after legalisation: 4 percentage points higher in men in 2004-2005 and nearly 8 percentage points in 2006-2007 . In subsequent years, the percentage of women and men in the total number of euthanasia procedures was relatively stable.

According to the law, euthanasia is allowed in various places. Initially, after legalisation, most euthanasia procedures were performed in hospitals $(54.1 \%$ in 2002-2003 and 53.6\% in 2004-2005), followed by the patients' homes (40.9\% and $39.2 \%$ respectively). The nursing home as a place of 'assisted death' was chosen in only about $5 \%$ of cases. In the following years, the percentage of acts of euthanasia carried out in hospitals gradually decreased, which was related to the increase in carrying out this procedure in patients' homes as well as nursing homes. In the period 2016-2017, 45.1\% of the euthanasia procedures performed took place in the patients' homes, $38.9 \%$ in hospitals and $13.9 \%$ in nursing homes. The percentage of euthanasia procedures in hospitals has, therefore, decreased compared to previous years. This change underlines the critical role of the family doctor in terms of considering the request for such a procedure, as well as its execution. The details are shown in Figure 3.

Over the last 16 years, the age structure of people undergoing euthanasia has changed. In the first years after legalisation, it could be observed that the percentage

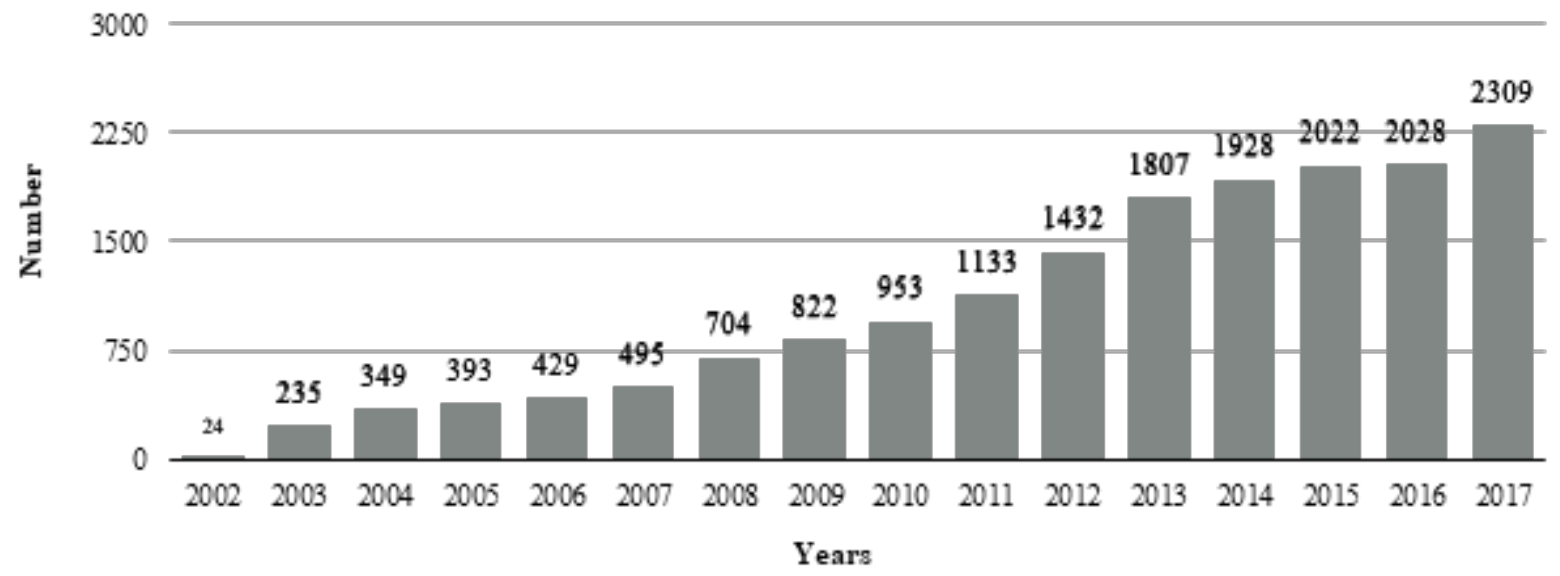

Fig. 1. Total number of euthanasia procedures carried out in Belgium in 2002-2017.

Ryc. 1. Całkowita liczba dokonanych eutanazji w Belgii w latach 2002-2017.

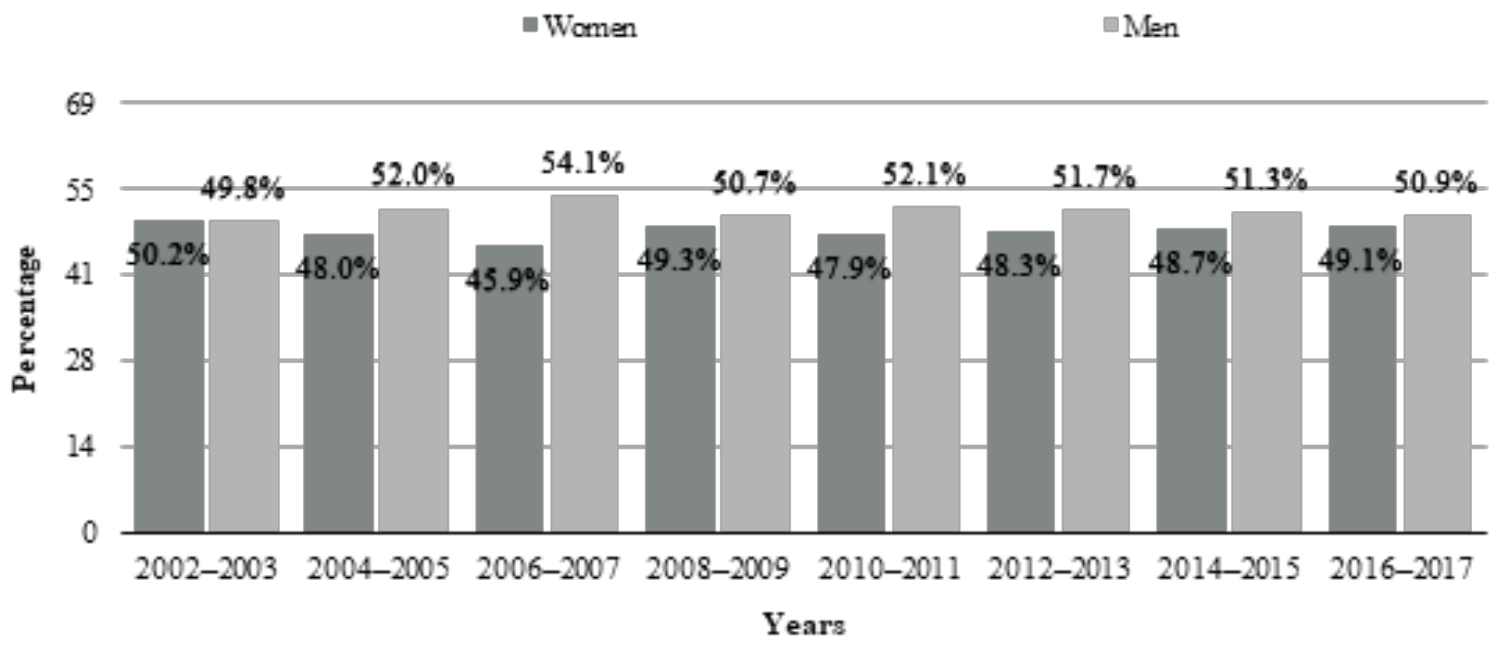

Fig. 2. Gender of persons subjected to euthanasia in individual years.

Ryc. 2. Odsetek osób poddanych eutanazji w poszczególnych latach z podziałem na płeć. 


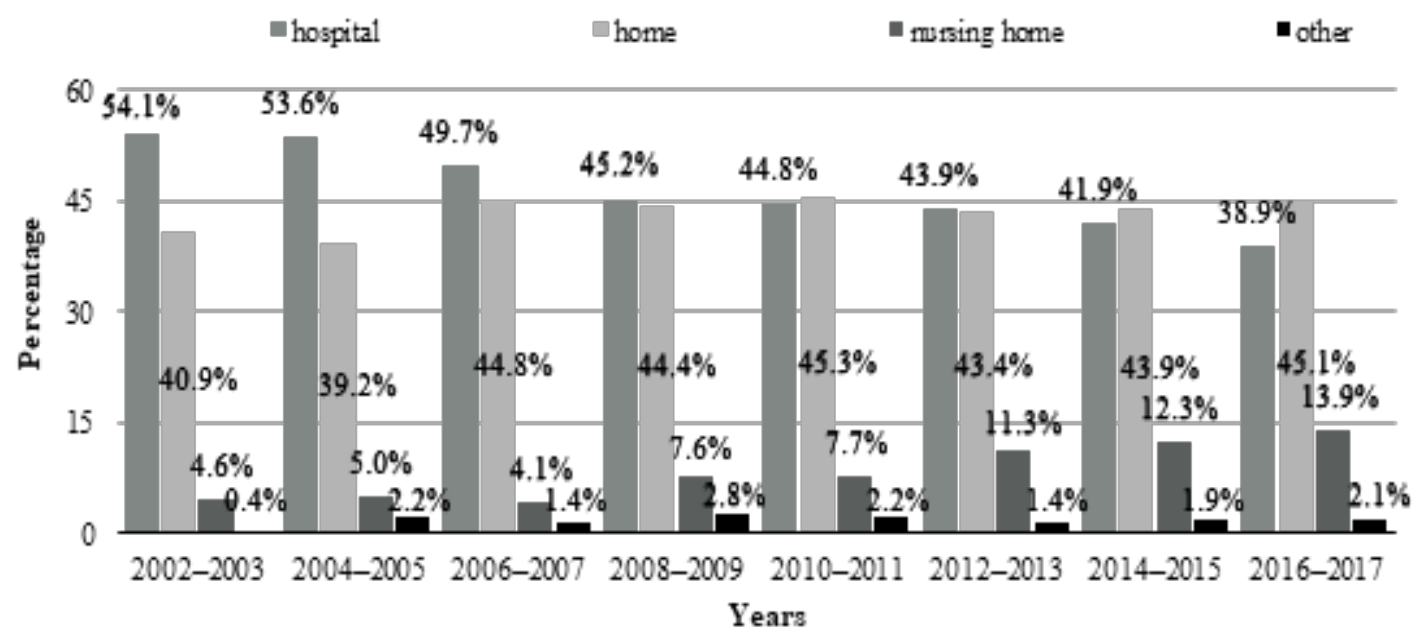

Fig. 3. Place of performing euthanasia over the years. Ryc. 3. Miejsce wykonania eutanazji na przestrzeni lat.

of people who were euthanised was the highest in the 60-79 age group (48.3\%), in the younger group (40-59 years of age) it was $32.0 \%$, while in people over $80-$ $16.2 \%$. In the following years, the percentage of older people (over 80) has increased, while the percentage of younger people undergoing this procedure decreased. Data from the latest 2016-2017 report indicate that euthanasia was performed in $1.4 \%$ of patients under 39 , $12.7 \%$ of patients aged $40-59,47.4 \%$ in patients aged $60-79$, and $38.5 \%$ in the case of patients aged $80-89$. Patients aged $90-99$ constituted $9.5 \%$ of cases, and patients over 100 years $-0.4 \%$ (Table I).

The reasons for euthanasia vary, but within the 16 years of legalisation, the most frequently cited reason is cancer. In 2002-2003, the percentage of acts of euthanasia due to cancer was nearly $83 \%$, while a little more than $17 \%$ were due to neuromuscular $(12.4 \%)$, respiratory $(1.2 \%)$, cardiovascular diseases $(2.3 \%)$ and other causes $(1.5 \%)$. Although cancer is still the primary reason for euthanasia, a downward trend can be observed. However, the percentage of other illnesses cited as the reason for euthanasia is increasing. According to the data presented in the 2016-2017 report, the leading cause was cancer $(64.1 \%)$. Other grounds for requesting euthanasia included multimorbidity (16.4\%), neuromuscular diseases $(6.9 \%)$, cardiovascular diseases $(3.9 \%)$, respi- ratory diseases $(3.2 \%)$ and others (3.7\%). The so-called 'other' diseases include trauma, toxicosis, osteoarticular diseases, connective tissue diseases, genitourinary and digestive diseases, AIDS, infectious and parasitic diseases, eye diseases, endocrine diseases, congenital malformations, skin, blood and haematopoietic diseases, as well as immune system disorders. The structure of reasons for performing euthanasia in the given years is presented in Table II.

Table I. Age of those subjected to euthanasia Tabela I. Wiek osób poddanych eutanazji

\begin{tabular}{ccccc}
\hline \multirow{2}{*}{ Years } & \multicolumn{4}{c}{ Age } \\
\cline { 2 - 5 } & $\leq 39$ & $40-59$ & $60-79$ & $\geq 80$ \\
\hline $2002-2003$ & $3.5 \%$ & $32.0 \%$ & $48.3 \%$ & $16.2 \%$ \\
$2004-2005$ & $6.3 \%$ & $28.2 \%$ & $48.8 \%$ & $16.7 \%$ \\
$2006-2007$ & $2.7 \%$ & $25.0 \%$ & $54.7 \%$ & $17.6 \%$ \\
$2008-2009$ & $1.9 \%$ & $21.5 \%$ & $51.8 \%$ & $24.8 \%$ \\
$2010-2011$ & $2.2 \%$ & $17.2 \%$ & $52.1 \%$ & $28.5 \%$ \\
$2012-2013$ & $1.9 \%$ & $15.9 \%$ & $48.5 \%$ & $33.7 \%$ \\
$2014-2015$ & $1.4 \%$ & $14.2 \%$ & $48.6 \%$ & $35.8 \%$ \\
$2016-2017$ & $1.4 \%$ & $12.7 \%$ & $47.4 \%$ & $38.5 \%$ \\
\hline
\end{tabular}


Table. II Reasons for euthanasia Tabela II. Przyczyny wykonanych eutanazji

\begin{tabular}{|c|c|c|c|c|c|c|c|}
\hline \multirow[b]{2}{*}{ Years } & \multicolumn{7}{|c|}{ Reasons for euthanasia } \\
\hline & Cancers & $\begin{array}{c}\text { Neuromuscular } \\
\text { diseases }\end{array}$ & $\begin{array}{c}\text { Respiratory } \\
\text { diseases }\end{array}$ & $\begin{array}{l}\text { Cardiovascular } \\
\text { diseases }\end{array}$ & $\begin{array}{c}\text { Neuropsychiatric } \\
\text { diseases }\end{array}$ & Multimorbidity & Other \\
\hline 2002-2003 & 82.6 & 12.4 & 1.2 & 2.3 & b.d. & b.d. & 1.5 \\
\hline 2004-2005 & 83.3 & 6.7 & 2.3 & 2.3 & 1.2 & 2.7 & 1.5 \\
\hline 2006-2007 & 81.2 & 8.8 & 1.9 & 2.4 & 1.0 & 1.7 & 3.0 \\
\hline 2008-2009 & 79.0 & 7.1 & 3.1 & 3.5 & 2.2 & 2.0 & 3.1 \\
\hline 2010-2011 & 75.1 & 7.6 & 2.9 & 5.3 & 2.8 & 1.9 & 4.4 \\
\hline 2011-2012 & 71.4 & 6.1 & 3.4 & 5.4 & 3.7 & 5.0 & 5.0 \\
\hline 2013-2015 & 67.7 & 6.9 & 3.1 & 5.2 & 3.1 & 9.8 & 4.2 \\
\hline 2016-2017 & 64.1 & 6.9 & 3.2 & 3.9 & 1.8 & 16.4 & 3.7 \\
\hline
\end{tabular}

\section{DISCUSSION}

Euthanasia is not a product of modern medicine; it was accepted and used already in ancient times. The Greeks explained euthanasia as a light, good death, without suffering. The meaning of euthanasia has changed over the centuries. In modern times, most philosophers and doctors have considered euthanasia to be a process of natural death, which is to be taken care of by all medical professionals through mental support and symptomatic treatment. In 1605, Francis Bacon used the word euthanasia for the first time, claiming that it is a doctor's duty to provide the patient with a peaceful and gentle death without pain and suffering. The nineteenth-century philosopher Nietzsche contended that a person should kill themselves if their life is only a source of worthless suffering to them.

The Second World War caused a radical change in thinking about euthanasia. In 1948, the United Nations introduced the Universal Declaration of Human Rights, which unconditionally protects the life and dignity of every human being. Topics related to euthanasia resurfaced in the late twentieth century, and social discussions as well as the development of various ethical attitudes were some of the stages leading to the legalisation of euthanasia in some countries in the twenty-first century [4].

The Netherlands was the first country in the world to legalise euthanasia. Since 1990, Dutch law stopped persecuting doctors for facilitating 'assisted death'; and the 'Termination of Life on Request and Assisted Suicide (Review Procedures) Act' granting the right to euthanasia came into force in 2002 [15]. Nonetheless, for 30 years, there have been constant debates about this procedure in the Netherlands. Interestingly, the word euthanasia is not used even once in the above Act. It includes 24 articles, only two of which refer to the criteria and conditions necessary to terminate life at the request of the patient, while the rest are purely informative and deal with the technical issues of euthanasia. It is also important to note that the Act does not provide a precise definition of 'termination of life on request' and thus does not fully define the term euthanasia [15]. Luxembourg is the third European country that has legalised euthanasia. The act legalising this procedure came into force in 2009 [16]. The laws concerning 'assisted death' are similar in all Benelux countries. In 2002, the Netherlands adopted a law allowing euthanasia and the assistance of doctors in carrying out this procedure which gave rise to similar legislation being approved in Belgium and Luxembourg. Notwithstanding, it should be noted that the Belgian law does not allow medical assistance in carrying out assisted death [17].

The statistics on the number of euthanasia acts performed in the Netherlands from 2002 to 2017 are similar to those for Belgium. The number of euthanasia procedures carried out each year increases [18]. Until 2003, there was a slight downward trend (1815 patients; in comparison, in 2000-2123), in 2004-2005 the number of acts of euthanasia started to increase until 2006 when another gradual decline was observed. The following years brought another increase, up to 5516 cases in 2015 [19,20,21,22].

In 2016, 6091 patients underwent euthanasia, with this number constituting $4 \%$ of the total number of deaths [23]. In 2017, 6585 euthanasia cases were reported (4.4\% of the total number of people who died in the Netherlands in 2017) [24]. These statistics do not include the number of euthanasia procedures performed outside the country, as well as those that may have been performed illegally.

Analysing the sex of people in the Netherlands, there is a slightly higher percentage of men than women who undergo euthanasia (in 2017 - 51.4\% men and 48.6\% women). Cancer remains the main reason for euthanasia reported in both years (2016-2017), followed by neurological disorders though much less frequently cited, in addition to cardiovascular and respiratory diseases [23,24].

At this point, attention should be drawn to the possible occurrence of issues in terms of pain management and the effectiveness of the applied analgesic pharmacotherapy. It may be necessary to intensify the treatment of pain and to broaden research on the possibilities of 
pain reduction. It is possible that an improvement in this respect would result in a decrease in the number of euthanasia cases. An additional aspect worth mentioning is psychological support of the patient. It would be advisable to consider introducing new methods to improve the mental condition of the patient, but also their family, who, being close to the person requesting euthanasia, certainly need support. These issues are not only a problem of the Benelux countries as they are universal and represent a challenge to public health.

In Poland, opinions on the legalisation of euthanasia are polarised, and there is no explicit consent for this type of practice $[25,26]$. Nevertheless, this topic resurfaces every now and then in the public debate. In the light of social changes and liberalisation of values, it cannot be ruled out that Poles will change their attitudes towards euthanasia. Along with the discussion on the possibility of terminating life earlier, there will be problems related not only to the ethical aspect but also to the psychological or legal factors. There are also questions about the possibilities and efficiency of palliative care, the support provided to the patient, as well as the options of pain management. All these questions are also becoming a challenge to public health in Poland. Given the demographic changes associated with an ageing population, the increase in the average life expectancy and the incidence of chronic diseases, the dilemmas of life, death and suffering cannot be overlooked. At the same time, it is impossible to precisely predict how the statistics would develop if euthanasia were legal in Poland.

In Belgium, euthanasia was most often performed in the groups of people aged 70-80, then $80-90$ and $60-70$ $[23,24]$. At the same time, it should be noted that the second most common reason for this type of death was multimorbidity, which is often typical of older age. Therefore, carrying out euthanasia in these age groups may also be for noncancerous reasons. Perhaps these patients are more likely to suffer from cardiovascular, respiratory or neurological disorders. Nonetheless, more statistical data are needed to understand these relationships fully. In Luxembourg, as in Belgium, the main reason for euthanasia is cancer. The question of how to deal not only with the already mentioned pain but also with loneliness, disability or problems in everyday life activities remains open. The accumulation of various pathological conditions may hinder psychological and social functioning, and thus intensify the feeling of pain, which in the patient's opinion, is unbearable.

Shortly after legalisation, the most frequent place of euthanasia in Belgium was the hospital, followed by the patients' homes. However, with time patients decided that their place of death should be the home. Data on euthanasia in the Netherlands in recent years show a similar pattern - the main places of assisted death are the patients' homes, and less often hospices, nursing homes or hospitals $[23,24]$. Based on the analysed data, it is not possible to precisely determine whether the reason for euthanasia and the place of its performance are related. However, it is possible that the place of death, which is the home, is chosen by patients suffering from chronic diseases, but not directly threatening their lives. On the other hand, this choice may be dictated by the patient's desire to spend their last moments in a friendly and familiar environment.

The issues of euthanasia, its legalisation and consequences are and will continue to be very controversial, particularly with regard to the novel provisions that provide for the possibility of euthanasia to minors. In Belgium, this possibility was allowed in 2014, and two years later, the first act of euthanasia on a minor was performed. Between 2016 and 2017, three euthanasia procedures were carried out in children and adolescents aged 9, 11 and 17 [6]. In the Netherlands, in 2016, one minor was euthanised, while in 2017, there were three more cases [23,24]. The Dutch legislation is not as far-reaching as the Belgian one but also allows for the euthanasia of minors, under certain conditions. Euthanasia in children aged 12-16 can only be performed with the voluntary consent of parents or legal guardians. In the Netherlands, there are two possibilities to give consent to terminate your own life: in writing or orally. Written consent is more important, especially if the person is no longer able to give consent orally and the doctor decides to euthanise.

The decision-making process is different when a patient is diagnosed with a mental illness. In such a case, the doctor is obliged to consult with two independent persons, including a psychiatrist [15]. Notwithstanding, it is important to note here the ethical doubts that will always exist, especially for minors, the mentally ill or patients in a coma. The rationale for carrying out euthanasia in the case of children, cited in the Report of the Belgian Federal Commission for Euthanasia Control and Evaluation, included incurable and severe illnesses that would result in death in a short time, such as Duchenne muscular dystrophy, malignant neoplasms of the eye, brain or other elements of the central nervous system (gliomas) and cystic fibrosis. In the Commission's view, extending the right to euthanasia to minors who are conscious of the decision they are making is sensible because it is intended to allow them a free choice to terminate their lives [6].

Discussions around euthanasia, independent of legal regulations, concern every society and become a challenge to public health due to the multidimensionality of the issue. The fact that euthanasia is not legal in Poland does not mean that there is no problem. One can even say that the relevant legislation is only the tip of the iceberg. Public discourse and scientific literature should take up such issues because behind them lurk the problems related to palliative care, coping with pain, suffering and the approach to other people. 


\title{
CONCLUSIONS
}

1. Since the legalisation of euthanasia in Belgium, the number of people who undergo this procedure has been continuously increasing.

2. In recent years, euthanasia is more frequently carried out in patients' homes and nursing homes.

3. The most common reasons for euthanasia include cancer.

\author{
Author's contribution \\ Study design - A. Wypych-Ślusarska \\ Data collection - I. Piękoś-Lorenc, M. Piecuch, W. Gajdzik \\ Data interpretation - I. Piękoś-Lorenc, W. Gajdzik \\ Statistical analysis - W. Gajdzik \\ Manuscript preparation - I. Piękoś-Lorenc, M. Piecuch, W. Gajdzik, A. Wypych-Ślusarska \\ Literature research - I. Piękoś-Lorenc, M. Piecuch, W. Gajdzik
}

\section{REFERENCES}

1. Kobyliński A. Nowy humanizm czy posthumanizm? Aspekty etyczno-prawne legalizacji eutanazji na świecie w latach 2000-2015. Studia Ecologiae et Bioethicae 2015; 13(4): 85-114

2. Pereira J. Legalizing euthanasia or assisted suicide: the illusion of safeguards and controls. Curr Oncol. 2011; 18(2): e38-45, doi: 10.3747/co.v18i2.883.

3. Szadkowska M. Zabójstwo eutanatyczne - tendencje liberalizacyjne w Europie na przykładzie Belgii. Studia Iuridica Toruniensia 2013; 13: 221-240. 4. Pacian J., Pacian A., Skórzyńska H., Kaczoruk M. Eutanazja - zabójstwo człowieka czy uśmierzenie bólu. Regulacje prawne wybranych państw świata. Hygeia Public Health 2014; 49(1): 19-25.

5. Derdziuk M. Praktyka eutanazji w Belgii jako owoc przemian społeczno-obyczajowych. Teologia i Moralność 2017; 12(2): 163-177.

6. Analyse du huitieme Rapport de la Commission Fedérale de Controle et d'Evaluation de l'Euthanasie aux Chambres Legislatives - (Annees 2016 et 2017), Institut Européen de Bioéthique, https://www.ieb-eib.org/ancien-site/ pdf/20181010-synthese-rap-com-euthan.pdf [data dostępu: 27.12.2018].

7. Premier Rapport de la Commission Fédérale de Contrôle et d'Évaluation de l'Euthanasie aux Chambres Législatives, (Années 2002 et 2003). Institut Européen de Bioéthique, https://organesdeconcertation.sante.belgique.be/fr/ documents/cfcee-rapport-euthanasie-2004 [data dostępu: 27.12.2018]. 8. Deuxième Rapport de la Commission Fédérale de Contrôle et d'Évaluation de l'Euthanasie aux Chambres Législatives, (Années 2004 et 2005). Institut Européen de Bioéthique https://organesdeconcertation.sante.belgique.be/fr/ documents/cfcee-rapport-euthanasie-2006 [data dostępu: 27.12.2018]. 9. Troisième Rapport de la Commission Fédérale de Contrôle et d'Évaluation de l'Euthanasie aux Chambres Législatives (Années 2006 et 2007). Institut Européen de Bioéthique, https://organesdeconcertation.sante.belgique.be/fr/ documents/cfcee-rapport-euthanasie-2008 [data dostępu: 27.12.2018]

10. Quatrieme Rapport de la Commission Fédérale de Contrôle et d'Évaluation de l'Euthanasie aux Chambres Législatives (Années 2008 et 2009). Institu Européen de Bioéthique, https://organesdeconcertation.sante.belgique.be/fr/ documents/cfcee-rapport-euthanasie-2010 [data dostępu: 27.12.2018] 11. Cinquieme Rapport de la Commission Fédérale de Contrôle et d'Évaluation de l'Euthanasie aux Chambres Législatives (Années 2010 et 2011). Institu Europeen de Bioethique, https://organesdeconcertation.sante.belgique.be/fr/ documents/cfcee-rapport-euthanasie-2012 [data dostępu: 27.12.2018] 12. Sixieme Rapport de la Commission Fédérale de Contrôle et d'Évaluation de l'Euthanasie aux Chambres Législatives (Années 2012 et 2013). Institut Europeen de Bioethique, https://organesdeconcertation.sante.belgique.be/fr/ documents/cfcee-rapport-euthanasie-2014 [data dostępu: 27.12.2018].

13. Septième Rapport de la Commission Fédérale de Contrôle et d'Évaluation de l'Euthanasie aux Chambres Législatives (Années 2014 et 2015). Institut
Européen de Bioéthique, https://organesdeconcertation.sante.belgique.be/fr/ documents/cfcee-rapport-euthanasie-2016 [data dostępu: 27.12.2018]

14. Huitième Rapport de la Commission Fédérale de Contrôle et d'Évaluation de l'Euthanasie aux Chambres Législatives (Années 2016 et 2017). Institut Européen de Bioéthique, https://derechoamorir.org/wp-content/ uploads/2018/09/2018-informe-eutanasia-belgica-2017.pdf [data dostępu: 27.12.2018].

15. Kobyliński A. Eutanazja w Holandii. Przegląd Powszechny 2003; 5: 335$-339$

16. Commission Nationale de Controle et d'Évaluation de la loi du 16 mars 2009 sur l'euthanasie et l'assistance au suicide. Quatrième rapport à l'attention de la Chambre des Deputés (Annees 2015 et 2016), https://sante.public.lu/fr/ publications/r/rapport-loi-euthanasie-2015-2016/quatrieme-rapport-loi-euthanasie-2015-2016.pdf [data dostępu: 27.12.2018]

17. Alichniewicz A. Wzorce śmierci w bioetyce amerykańskiej. Kraków 2007 , s. $95-103$

18. Pays-Bas: accroissement de $10 \%$ des cas d'euthanasie en 2016. Institut Européen de Bioéthique - Bruxelles. 2017.

19. Regionale Toetsingscommissies Euthanasie Jaarverslag 2003, https://www. euthanasiecommissie.nl/uitspraken/jaarverslagen/2003/nl-en-du/nl-en-du/jaarverslag-2003 [data dostepu: 27.12.2018].

20. Regionale Toetsingscommissies Euthanasie Jaarverslag 2006, https://www. euthanasiecommissie.n1/uitspraken/jaarverslagen/2006/nl-en-du-fr/nl-en-du-fr/ jaarverslag-2006 [data dostępu: 27.12.2018]

21. Regionale Toetsingscommissies Euthanasie Jaarverslag 2009, https://www. euthanasiecommissie.nl/uitspraken/jaarverslagen/2009/nl-en-du-fr/nl-en-du-fr/ jaarverslag-2009 [data dostępu: 27.12.2018]

22. Regionale Toetsingscommissies Euthanasie Jaarverslag 2015, https:// www.euthanasiecommissie.nl/uitspraken/jaarverslagen/2015/april/26/jaarverslag-2015 [data dostępu: 27.12.2018]

23. Regionale Toetsingscommissies Euthanasie Jaarverslag 2016, https:// www.euthanasiecommissie.nl/uitspraken/jaarverslagen/2016/april/12/jaarverslag-2016 [data dostepu: 01.01.2019].

24. Regionale Toetsingscommissies Euthanasie Jaarverslag 2017, https:/ www.euthanasiecommissie.nl/uitspraken/jaarverslagen/2017/mei/17/jaarverslag-2017 [data dostępu: 01.01.2019].

25. Sierżantowicz R., Łagoda K., Doroszkiewicz H., Jurkowska G. Opinie lekarzy, pielegniarek, pacjentów i studentów na temat eutanazji. Gerontol. Pol. 2011; 19(2): 99-106.

26. Centrum Badania Opinii Społecznej. Komunikat z badań, BS/3/2013, Zaniechanie uporczywej terapii a eutanazja. Warszawa 2013, https://www.cbos.pl/ SPISKOM.POL/2013/K 003 13.PDF 